\title{
Inheritance of an Induced Chlorophyll Mutant in Oats (Avena Sativa) ${ }^{1}$
}

\author{
R. Abrams, ${ }^{2}$ R. Grindeland, ${ }^{3}$ and K. J. Frey ${ }^{3}$
}

\section{INTRODUCTION}

The frequency of spontaneous mutations which affect chlorophyll production or plant color is very low in hexaploid oats. Probably spontaneous chlorophyll deficiencies in oats were reported first by Nilsson-Ehle (7), ${ }^{4}$ who found white plants in three different hexaploid oat varieties. According to De Haan (3), Zhegulov, as early as 1920, found that ar chlorophyll deficiency called "albina" showed Mendelian inheritance, and Akerman (1) discovered a lutescens strain in a cross of Swedish Black Hulled $x$ Probsteier oats. The lutescens seedlings were green upon emergence, but became yellow upon exposure to bright light and died within a few weeks. This attribute was conditioned by three recessive genes.

Akerman and Froier (2) found the chlorophyll mutant, chlorina, in Goldregn I oats. Chlorina seedlings were yellow-green and stunted in growth, but they lived to maturity. Three genes conditioned the inheritance of the chlorina type. Another chlorina type, Golden, inherited as a recessive, was reported by Morey and Earhart (6).

Froier (4) found the following irradiation-induced chlorophyll mutants in hexaploid oats: Albina, viridoalbina, virescens, and lutescens. All were inherited as recessives, with some segregating on a single factor-pair basis.

Reported here is an analysis of the mode of inheritance of a chlorophylldeficient mutant found at Ames, Iowa, in a mutagen-derived population of hexaploid oats.

\section{MATERIALS AND METHODS}

In the $\mathrm{M}_{1}$ generation obtained by treating oat seed of Clintland 60 variety with a combination of $\mathrm{P}_{32}$ and ethyl methane sulfonate, ${ }^{5}$ one tiller of

1 Journal Paper No. J-4505 of the Iowa Agricultural and Home Economics Experiment Station, Ames, Iowa. Project No. 1176. In cooperation with the Crops Research Division, ARS, USDA.

3 Graduate student, Agronomy Dept., Iowa State University, Ames, Iowa; currently Associate Plant Breeder, Agricultural Experiment Station of University of Puerto Rico, Isabela Substation, Isabela, P.R.

3 Agricultural Research Technician, CRD, ARS, USDA, and Professor of Agronomy, respectively, Iowa State University, Ames, Iowa.

4 Italic numbers in parentheses refer to Literature Cited, p. 246.

5 Seed were immersed in a 0.12 -molar solution of ethyl methane sulfonate at room temperature for 2 hours, rinsed in tapwater, and immersed in a $P_{32}$ solution (1 $\mu \mathrm{c}$ per seed) for 72 hours. 
one plant was found which showed a white stripe in the midvein region of the leaves, stem, and glumes. The other tillers were normal green. At anthesis florets on both the stripe and green tillers were pollinated with pollen from C $649^{6}$ variety of oats. Selfed seeds from the striped and normal tillers were also saved to study segregation. Plants from the $F_{1}, F_{2}$, and $\mathrm{M}_{2}$ generations were grown and classified in the greenhouse at Ames, Iowa, during the 1961-62 winter season.

The $F_{1}$ seedlings were normal in color and growth. None of the $F_{2}$ or $\mathrm{M}_{2}$ seedlings showed the striping character, but these populations did segregate seedlings with a chlorophyll deficiency similar to Froier's (4) albovirescens and Gustafsson's (5) viridoalbina. To verify the $F_{2}$ generation classification, $\mathrm{F}_{3}$ and $\mathrm{M}_{3}$ progeny rows were grown and classified in the field at Ames in the summer of 1962.

\section{RESULTS}

No striped seedlings were found in any of the generations subsequent to the $\mathrm{M}_{1}$. The leaves of the albovirescens plants in the $\mathrm{M}_{2}, \mathrm{M}_{3}, \mathrm{~F}_{2}$, and $\mathrm{F}_{3}$ generations were white when they emerged from the whorl, but after 3 days, the leaf tips showed some green color and eventually the entire leaves became green. The green color of the albovirescens plants was more pale than that of the normal plants, but the plants were sufficiently vigorous to produce some seed. Actually the chlorophyll deficiency and associated stunting were more pronounced in the field than in the greenhouse.

Of the $F_{2}$ progenies from the six $F_{1}$ plants, only one segregated for the albovirescens characteristic. This $F_{1}$ progeny was derived from a cross made on the striped tiller of the $M_{1}$ plants. However, the $M_{2}$ generation from both tillers showed segregation for the albovirescens character. The observed numbers of green and albovirescens seedlings in the $\mathrm{F}_{2}$ generation of the cross were 42 and 9 , respectively. These data gave a satisfactory fit to a 3:1 ratio, indicating that segregation was occurring at only one locus with the albovirescens characteristic being inherited as a recessive. All the normal green and seven of albovirescens $F_{2}$ plants produced seed, which were planted for $\mathrm{F}_{3}$ progeny tests. The seven progenies from the albovirescens plants contained either all green or both green and albovirescens seedlings. Only 14 of the 42 were segregating, whereas the expected number for inheritance on a single factor basis would be 28 .

Since nearly half of the nonsegregating progenies had fewer than 10 seedlings, the authors feel that a number of the progenies from heterozygous $\mathrm{F}_{2}$ plants did not show albovirescens seedlings because of inadequate progeny size. Of course, mistakes in classification because of inadequate

${ }^{6}$ (Clintland $^{8} \times$ RL 2105) $x$ (Clintland ${ }^{7} \times$ RL 2105). 
progeny size would occur only in the direction of misclassifying segregating progenies.

The seedlings produced in the 14 segregating $F_{3}$ progenies segregated 148 green to 59 albovirescens. These data also fit a $3: 1$ ratio, which substantiates the single-factor hypothesis.

A further test of the mode of inheritance of the albovirescens character was provided by the seedlings in the $\mathrm{M}_{2}$ population. They segregated 170 green to 57 albovirescens which was nearly a perfect fit to a 3:1 ratio. Seed obtained from 154 of the $\mathrm{M}_{2}$ plants were planted in $\mathrm{M}_{3}$ progeny rows, and, as with the hybrid-derived material, there was a deficiency of segregating rows here also, i.e. 53 green, 63 segregating, and 38 albovirescens. However, when the homozygous green and segregating progenies were pooled, the ratio of this class to albovirescens fitted a $3: 1$ ratio, i.e. 116 green segregating and 38 albovirescens. The shortage of segregating $\mathrm{M}_{3}$ progenies was probably caused by inadequate sample size in many of the progenies.

All of the data from the $F_{2}$ and $F_{3}$ generations of the oat cross, Mutant x C 649, and the $M_{2}$ and $M_{3}$ generations directly from the mutant plant suggested that the albovirescens characteristic was inherited as a recessive on a single factor-pair basis.

The chlorophyll-defective mutation isolated from the oats treated with ethyl methane sulfonate and $\mathrm{P}_{32}$ has been classified tentatively as albovirescens (4). The genetic relationship between Froier's albovirescens and the mutant described here has not been tested; therefore it is not possible to know whether both are conditioned by the same gene or even represent the same locus. If it does not represent the same mutation described by Froier, the genetic condition of albovirescens seedlings would be $a v a v$.

\section{SUMMARY}

A chlorophyll-defective mutation identified as albovirescens was isolated from hexaploid oats, Clintland 60 variety, treated with ethyl methane sulfonate and $P_{32}$. Study of the $F_{2}$ and $F_{3}$, and $M_{2}$ and $M_{3}$ generations in which this mutation was segregating showed that the albovirescens character was conditioned by a recessive gene in the homozygous condition.

A deficiency of progenies in the segregating classes of the $F_{3}$ and $M_{3}$ probably resulted from the many cases of inadequate sample size within progenies.

\section{RESUMEN}

Una mutación deficiente en clorofila, identificada como albovirescens, se aisló de una avena hexaploide, variedad Clintland 60, tratada con metano etílico sulfonado y $P_{32}$. Un estudio de las generaciones $F_{2}$ y $F_{3}$ y $M_{2}$ y $M_{3}$, en las cuales esta mutación estaba en proceso de segregación demostró que 
el carácter albovirescens estaba condicionado por un gene recesivo en el estado homozigótico.

La deficiencia de progenies en las clases segregadoras de las generaciones $\mathrm{F}_{3}$ y $\mathrm{M}_{3}$ se debió, probablemente, a que el tamaño de las muestras de las progenies que se estudiaron era inadecuado.

\section{LITERATURE CITED}

1. Akerman, A., Untersuchungen uber eine in derektem Sonnenlichte nicht lebensfagige Sippe von Avena sativa, Hereditas 3 147-77, 1922.

2. Akerman, A., and Froier, K., Studien uber eine spontane chlorinamutation in Avenasativa, Hereditas 27 371-404, 1941.

3. De Haan, H., Inheritance of chlorophyll deficiencies, Bibliog. Genét. 10 357-412, 1933.

4. Froier, K., Genetical studies on the chlorophyll apparatus in oats and wheat, Hereditas 32 297-406, 1946.

5. Gustafsson, A., The Mutation System of the Chlorophyll Apparatus, Lunds Univ. Arssk NF, Avd. 2, 36 (11), 1940.

6. Morey, D. D., and Earhart, R. W., Golden oats, J. Hered. 43 181-82, 1952.

7. Nilsson-Ehle, H., Einige Beobachtungen uber erbliche Variationen der Chloropbylleigenschaft bei den Getreidearten, $Z$. Ind. Abstammungs-u. Vererbungslehre 9 289-300, 1913. 